\title{
Taxonomy of an endemic Aristolochia (Aristolochiaceae) from the Iberian Peninsula
}

\author{
by \\ Andrea Costa \\ Departamento de Biodiversidad, Real Jardín Botánico, CSIC, Plaza de Murillo 2, 28014 Madrid, Spain. andrea.baccello@gmail.com
}

\begin{abstract}
Costa, A. 2008. Taxonomy of an endemic Aristolochia (Aristolochiaceae) from the Iberian Peninsula. Anales Jard. Bot. Madrid 65(2): 173-178.

The taxonomy of an Iberian endemic Aristolochia is treated, based on morphological and cytological characters. A brief description of its main diagnostic characters, distribution and habitat is included, as well as a distribution map and a few comments on its possible phylogenetic relationships. A new combination is proposed, raising this taxon from subspecies to a species proper: A. castellana (Nardi) Costa. A revised dichotomous key for the Iberian taxa of the genus is proposed.
\end{abstract}

Keywords: Aristolochia pallida subsp. castellana, Aristolochia castellana, morphology, acid plutonic rock, granite, dichotomous key for the Iberian Aristolochia species.

\section{Introduction}

During a trip in central Spain, in 1986, an interesting new taxon of Aristolochia from the Iberian Peninsula was discovered (Nardi, 1988; Ball \& al., 1993).

The overall vegetative appearance, with the exception of a general reduced size of all parts, strikingly resembled A. lutea Desf., a common Central-Eastern Mediterranean species (Ball \& al., 1993). A. lutea belongs to the group $A$. pallida, together with $A$. pallida Willd., a mainly Central Mediterranean species, and a few endemic species from the Central-Eastern Mediterranean.

The chromosome number turned out to be $2 n=10$, different from $A$. lutea $(2 n=8$; Fabbri \& Fagioli, 1971; Nardi, 1984), but the same as A. pallida and that of most of the species belonging to this group (Nardi, 1984; 1988; 1989; 1991; Nardi \& Nesi Nardi, 1987; Ball \& al., 1993; Constantinidis \& al., 1997).

All the samples then collected by Nardi seemed to

\section{Resumen}

Costa, A. 2008. Taxonomía de una Aristolochia (Aristolochiaceae) endémica de la Península ibérica. Anales Jard. Bot. Madrid 65(2): 173-178 (en inglés).

El presente trabajo trata la taxonomía de una Aristolochia endémica de la Península Ibérica, basándose en caracteres morfológicos y citológicos. Se incluye una breve descripción de los caracteres diagnósticos principales, de su distribución y hábitat, así como un mapa de su distribución y algunos comentarios sobre sus posibles relaciones filogenéticas. Se propone una nueva combinación, ascendiendo el taxon de subespecie a especie: $A$. castellana (Nardi) Costa. Se propone una nueva clave dicotómica para los táxones del género presentes en la Península Ibérica.

Palabras clave: Aristolochia pallida subsp. castellana, Aristolochia castellana, morfología, roca plutónica ácida, granito, clave dicotómica para las especies ibéricas de Aristolochia.

show a globous hypocotyledonary tuberous rootstock, in accordance with the main morphological features of the group; the alternative type, the elongated one, on the contrary, being typical of the $A$. longa, or A. paucinervis or $A$. fontanesii, group (Nardi, 1984).

All these characteristics (vegetative features, rootstock form and chromosome number) convinced Nardi that the new taxon could be described as A. pallida subsp. castellana Nardi (Nardi, 1988 and pers. comm.), which then became the westernmost of the group and the only one present in the Iberian Peninsula.

During later investigations (Costa, 2002), new collections and observations were carried out on this Iberian taxon, leading to somewhat different conclusions.

\section{Materials and methods}

Main diagnostic features measurements of the leaf and flower (Table 1, upper part) were taken from 
about 20 different herbarium specimens belonging to MA, MACB, MAF and FI (see Appendix).

Special care had been taken when choosing the leaves and the corresponding axillary flower sampled: only completely developed leaves, from the central part of the stem, had been taken into account, avoiding precocious ones (always of reduced size) and also those too young, from the upper part of the stem.

The presence of an inferior, narrow ovary makes difficult the recognition of the peduncle ends. To overcome this problem, we have decided to take into account the sum of the peduncle plus the ovary for the comparisons.

All the new cited measurements of the tuberous rootstock (Table 1, lower part) correspond to living plants from the Alto del Mirlo (Madrid and Ávila, Sierra de Gredos), cultivated in pots for a few years; eventually, these plants unfortunately died.

\section{Taxonomic teatment}

From a morphological point of view, the vegetative features of the original description have been confirmed, apart from a general slightly wider range of variation (Table 1 , upper part).

Surprisingly, however, the subterranean tuberous rootstock has proven to belong to the elongated type: in young individuals the general shape seems closer to the globous type, but starts elongating in a little older ones (Fig. 1), reaching a notable length in old plants (Table 1, lower part).

All the samples of the holo- and isotypus (Nardi, 1988) are clearly young individuals, which fail to offer a proper representation of the rootstock characteristics.

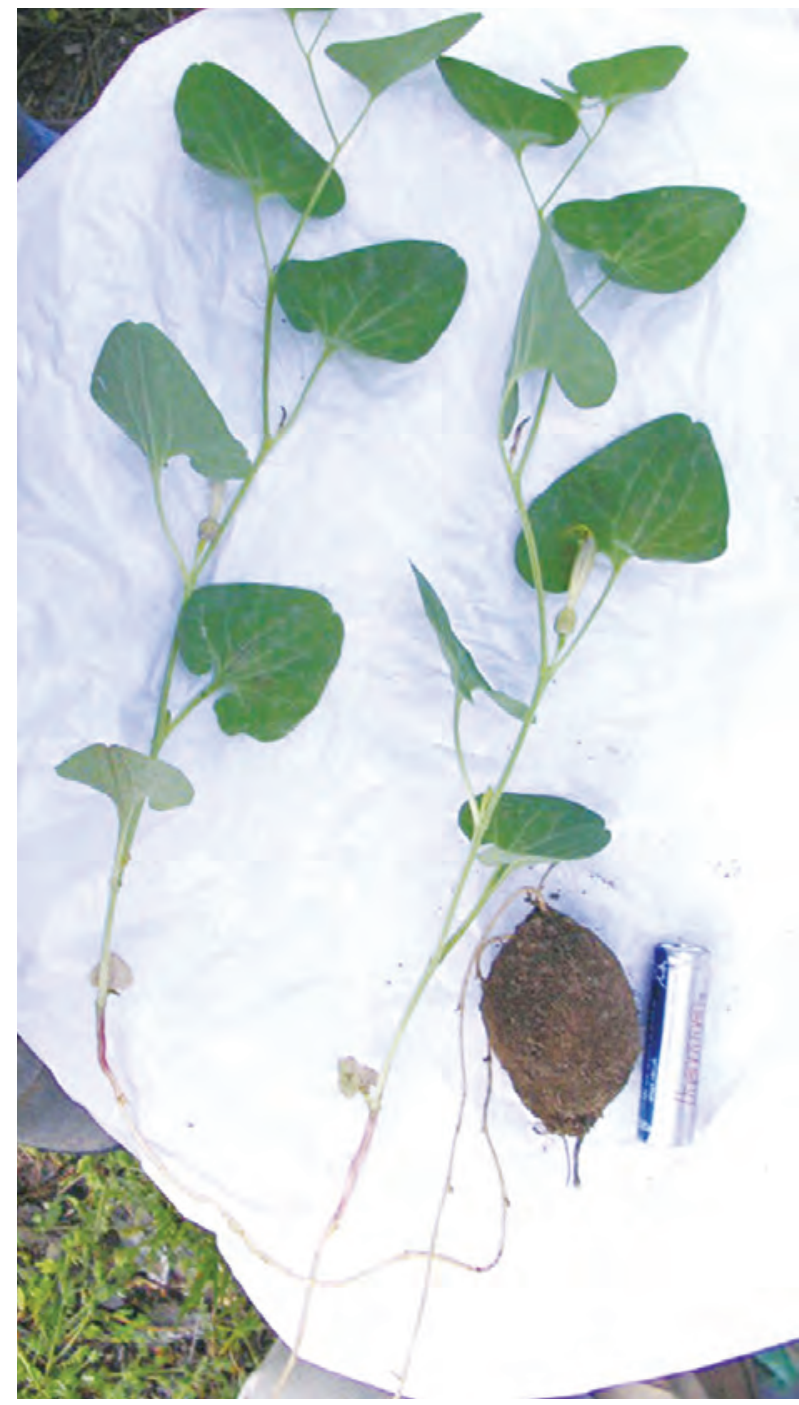

Fig. 1. An individual of Aristolochia castellana from Ávila, Casillas. Picture by the author.

Table 1. Comparison of the main features measurements of the Aristolochia castellana with the protolog (Nardi, 1988). In the lower part are some examples of the size of the tuberous rootstock from samples collected in the Alto del Mirlo (Madrid and Ávila, Sierra de Gredos). In mm; l, length; w, width; bw, width at the base.

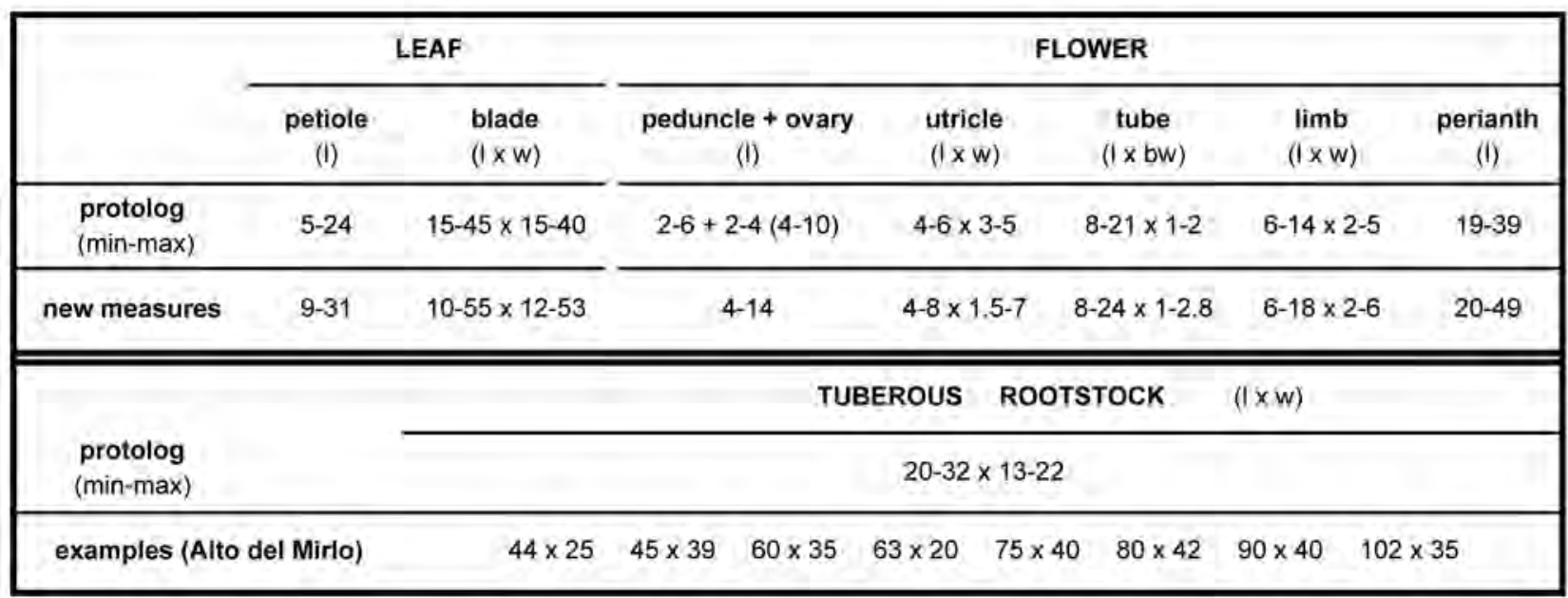


In Table 2 the morphological features of $A$. pallida subsp. castellana are compared with the apparently more related species, such as $A$. pallida subsp. pallida, $A$. lutea and $A$. paucinervis Pomel, the latter always found growing intermixed in the same localities (the data for these other species come from another work in preparation by the author).

As opposed to $A$. pallida subsp. pallida, A. pallida subsp. castellana shares the chromosome number $(2 n$ $=10$ ), like other species belonging to the same group, and some morphological characteristics, such as the leaf shape and the petiole/(peduncle + ovary) ratio. But other features are different: the flower limb is bigger in A. pallida subsp. pallida and the extremely important diagnostic character of the flower limb/tube length ratio is significantly different, being $>1$ for $A$. pallida subsp. pallida, whilst $<1$ for $A$. pallida subsp. castellana. Moreover, the tuberous rootstock shape, as was previously noted, belongs to the elongated type in $A$. pallida subsp. castellana, whilst belonging to the globous type in A. pallida subsp. pallida.

The overall vegetative appearance of $A$. pallida subsp. castellana is very similar to that of $A$. lutea, apart from the generally reduced size of all parts and the petiole/(peduncle + ovary) ratio, which is usually higher in A. pallida subsp. castellana. Moreover, the chromosome number $(2 n=8$ for $A$. lutea $)$ and the tuberous rootstock are different, the latter being clearly globous in $A$. lutea.

The elongated tuberous rootstock type is the same as that of $A$. paucinervis, which is always found growing intermixed with $A$. pallida subsp. castellana. But $A$. paucinervis, which has a very much wider distribution (France, Iberian Peninsula and North Africa) and is probably polyploid $(2 n=36$; Nardi, 1984), has significantly different vegetative characteristics (Table 2): generally shorter petiole; a significantly lower petiole/(peduncle + ovary) ratio; generally bigger leaf blade with a more elongated shape; usually bigger flowers, with the tube proportionally wider at the base.

All the above mentioned features caused us to doubt as to the correct taxonomic treatment of this new Iberian taxon, which would appear to have all the characteristics for being considered an endemic species proper.

Thus I propose the following new combination: Aristolochia castellana (Nardi) Costa, comb. \& stat. nov. [Aristolochia pallida subsp. castellana Nardi, Webbia, 42: 15, 16 fig. 1. 1988, basión. Holotypus: Spain. Ávila: Cuevas del Valle, 24-V-1986, Nardi E Nesi Nardi 8615 (FI; isotypus, MA 485799)].

Here below is a proposed modified dichotomous key for the Iberian taxa of the genus Aristolochia (compare with Castroviejo, 1986; Ball \& al., 1993):

\section{KEY OF ARISTOLOCHIA (ARISTOLOCHIACEAE)}

1. Clustered flowers

A. clematitis

1. Solitary flowers

A. baetica

2. Climbing plant

2. Erect, ascending or prostrate plant

Table 2. Comparison of the morphological characteristics of Aristolochia castellana with some apparently related species. The data for A. castellana correspond to 64 leaves from 26 stems; A. pallida 66 leaves / 30 stems; A. lutea 116/50; A. paucinervis 81 / 48. In mm; $\mathrm{mw}$, maximum width; the rest of legend as Table 1.

\begin{tabular}{|c|c|c|c|c|c|c|c|c|c|c|c|c|}
\hline & \multicolumn{2}{|r|}{ LEAF } & \multicolumn{6}{|c|}{ FLOWER } & \multicolumn{4}{|c|}{ RATIOS } \\
\hline & $\begin{array}{l}\text { petiole } \\
\text { (1) }\end{array}$ & $\begin{array}{l}\text { biade } \\
(I \times-w)\end{array}$ & $\begin{array}{l}\text { peduncle } \\
\text { ₹ ovary (I) }\end{array}$ & $\begin{array}{l}\text { utricie } \\
(1 \times W)\end{array}$ & $\begin{array}{l}\text { tube } \\
(1 \mathrm{x} \text { bw) }\end{array}$ & (mw) & $\operatorname{limb}_{(1 \times w)}$ & $\begin{array}{l}\text { perianth } \\
\text { (i) }\end{array}$ & $\begin{array}{l}\text { leaf blade } \\
(1 / w)\end{array}$ & pet / (ped+ov) & $\begin{array}{c}\text { limb / tube } \\
\text { (1/1) }\end{array}$ & $\begin{array}{c}\text { tube } \\
(\mathrm{mw} / \mathrm{bw})\end{array}$ \\
\hline \multirow{2}{*}{$\begin{array}{l}\text { A. castellana } \\
\text { (min-max) } \\
\text { average } \pm \mathrm{SD}\end{array}$} & $9-31$ & $10-55 \times 12-53$ & $4-14$ & $4-8 \times 1.5-7$ & $8-24 \times 1-28$ & $3-7$ & $6-18 \times 2-6$ & 20.49 & $0.70-1.22$ & $1.64-5.80$ & $0.33-1.00$ & $1.50-4.50$ \\
\hline & $19.2 \pm 5,2$ & $\begin{array}{l}\text { (1) } 33.9 \pm 10.0 \\
\text { (w) } 34.6 \pm 8.7\end{array}$ & $6.7 \pm 1.6$ & $\begin{array}{l}5.7 \pm 0.8 \\
4.1 \pm 1.2\end{array}$ & $\begin{array}{c}15.4 \pm 3.0 \\
1.9 \pm 0.4\end{array}$ & $4.6 \pm 0.9$ & $\begin{array}{c}10.1 \pm 2.0 \\
4.2 \pm 0.8\end{array}$ & $31.2 \pm 5.0$ & $0.97 \pm 0.11$ & $2.95 \pm 0.87$ & $0.67 \pm 0.13$ & $2.54 \pm 0.57$ \\
\hline \multirow[b]{2}{*}{ A. pallida } & $6-30$ & $23-72 \times 27-65$ & $3-9$ & $4-10 \times 3-7$ & $8-24 \times 1.2$ & $3-7$ & $10-26 \times 4-12$ & $24-57$ & $0.72-1.11$ & $1.22-6.00$ & $0.64-2.09$ & $2.00-5.00$ \\
\hline & $17.6 \pm 5.4$ & $\begin{array}{l}42.4 \pm 9.5 \\
43.3 \pm 8.8\end{array}$ & $6.2 \pm 1.5$ & $\begin{array}{l}6.3 \pm 1.4 \\
4.4 \pm 0.8\end{array}$ & $\begin{array}{c}14.0 \pm 3.4 \\
1.8 \pm 0.3\end{array}$ & $5.1 \pm 0.8$ & $\begin{array}{c}17.8 \pm 3.7 \\
6.9 \pm 1.8\end{array}$ & $38.1 \pm 6.9$ & $0.98 \pm 0.08$ & $2.96 \pm 0.98$ & $1.31 \pm 0.31$ & $2.92 \pm 0.59$ \\
\hline \multirow[b]{2}{*}{ A. Iutea } & $7-27$ & $25-62 \times 22-67$ & $3-22$ & $5-13 \times 3-7$ & $5-35 \times 1-3$ & $4-10$ & $7-23 \times 3-8$ & $27-69$ & $0.72-1.33$ & $0.59-5.00$ & $0.34-0.95$ & $1.67-769$ \\
\hline & $12.5 \pm 3.4$ & $\begin{array}{l}40.9 \pm 8.5 \\
41.1 \pm 8.4\end{array}$ & $7.5 \pm 2.6$ & $\begin{array}{l}8.1 \pm 1.5 \\
5.0 \pm 0.9\end{array}$ & $\begin{array}{c}23.6 \pm 5.4 \\
2.0 \pm 0.3\end{array}$ & $6.0 \pm 11$ & $\begin{array}{c}14.5 \pm 2.7 \\
4.9 \pm 10\end{array}$ & $46.3 \pm 7.8$ & $1.00 \pm 0.11$ & $1.83 \pm 073$ & $0.63 \pm 0.13$ & $3.04 \pm 0.75$ \\
\hline \multirow[b]{2}{*}{ A. paucinervis } & $5-21$ & $31.74 \times 27.65$ & $6 \cdot 21$ & $4-8.5 \times 3-8$ & $10-33 \times 1.5-5$ & $4-8$ & $5-24 \times 2-9$ & $28-64$ & $0.88-1.78$ & $0.45-2.50$ & $0.23-1.40$ & $1.10-4.00$ \\
\hline & $11.5 \pm 3.6$ & $\begin{array}{c}48.4 \pm 10.7 \\
41.7 \pm 8.5\end{array}$ & $10.3 \pm 2.7$ & $\begin{array}{l}6.2 \pm 1.0 \\
5.9 \pm 1.0\end{array}$ & $\begin{array}{c}22.7 \pm 5.0 \\
3.4 \pm 0.6\end{array}$ & $6.1=0.9$ & $\begin{array}{c}14.8 \pm 3.3 \\
4.8 \pm 1.2\end{array}$ & $43.6 \pm 7.8$ & $1.16 \pm 0.15$ & $1.16 \neq 0.37$ & $0.67 \pm 0.18$ & $1.86 \pm 0.43$ \\
\hline
\end{tabular}


3. Sessile or subsessile, semi-amplexicaul leaves .... A. rotunda

3. Petiolate, never amplexicaul leaves

4. Fasciculate, rhizomatous woody roots, without a tuberous rootstock; flower tube cylindrical, flower limb much wider than tube and clearly revolute at the base; leaves densely hairy on both surfaces, with a noticeable cartilaginous and hairy margin, often undulate; main veins on the inferior surface cartilaginous and hairy

A. pistolochia
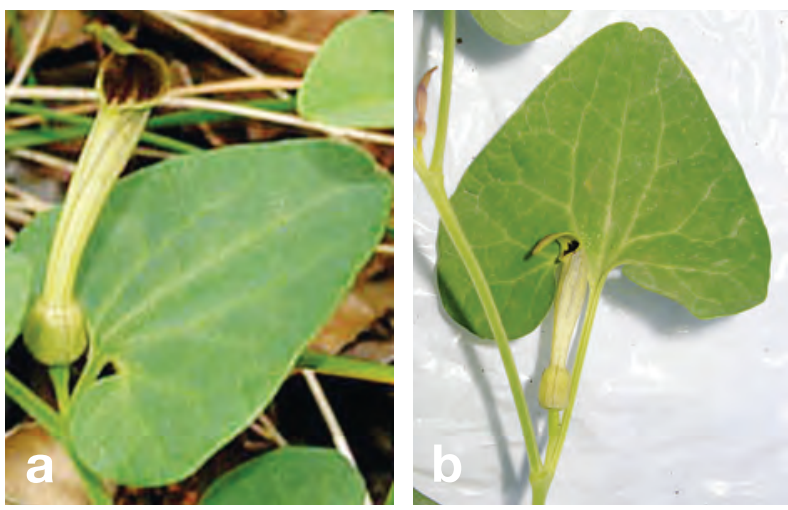

Fig. 2. Details of the main characteristic diagnostic features of: a, Aristolochia paucinervis; b, A. castellana. Picture (a) by C. Botella from the Internet: Herbario Jaca, Gobierno de Aragón (http://www.ipe.csic.es/floragon/index.php); picture (b) by the author (the same individual as in Fig. 1).
4. With a tuberous rootstock; flower tube obconic, clubshaped, flower limb slightly wider than tube and slightly revolute at the base; leaves glabrous to sparcely hairy, mainly on the lower surface, with a glabrous, weakly cartilaginous, entire margin; main veins on the inferior surface weakly cartilaginous and glabrous or sparcely hairy

5. Generally prostrate stems; clearly elongated mature leaves, 16-35 × 5-20 mm, glabrous; flowers 10-30 mm long

A. bianorii

5. Generally ascending stems; generally as long as wide or slightly elongated mature leaves, 10-74 × 12-65 mm, weakly haired, mainly on the lower surface; flowers 20-64 mm long

6. In completely developed leaves, petiole length more or less equal to the relative flower peduncle + ovary length (Fig. 2a); perianth tube slightly narrower at the base, the maximum width usually around double that of the width at the base (Table 2, mw / bw); leaves laminae usually slightly elongated, almost glabrous on the upper surface

A. paucinervis

6. In completely developed leaves, petiole clearly longer than the relative flower peduncle + ovary (Fig. 2b); perianth tube clearly narrower at the base, the maximum width usually more than double that of the width at the base (Table 2, mw / bw); leaves laminae usually more or less as long as wide, weakly hairy

A. castellana

\section{Distribution and habitat}

Similar to other endemic species of the genus in the

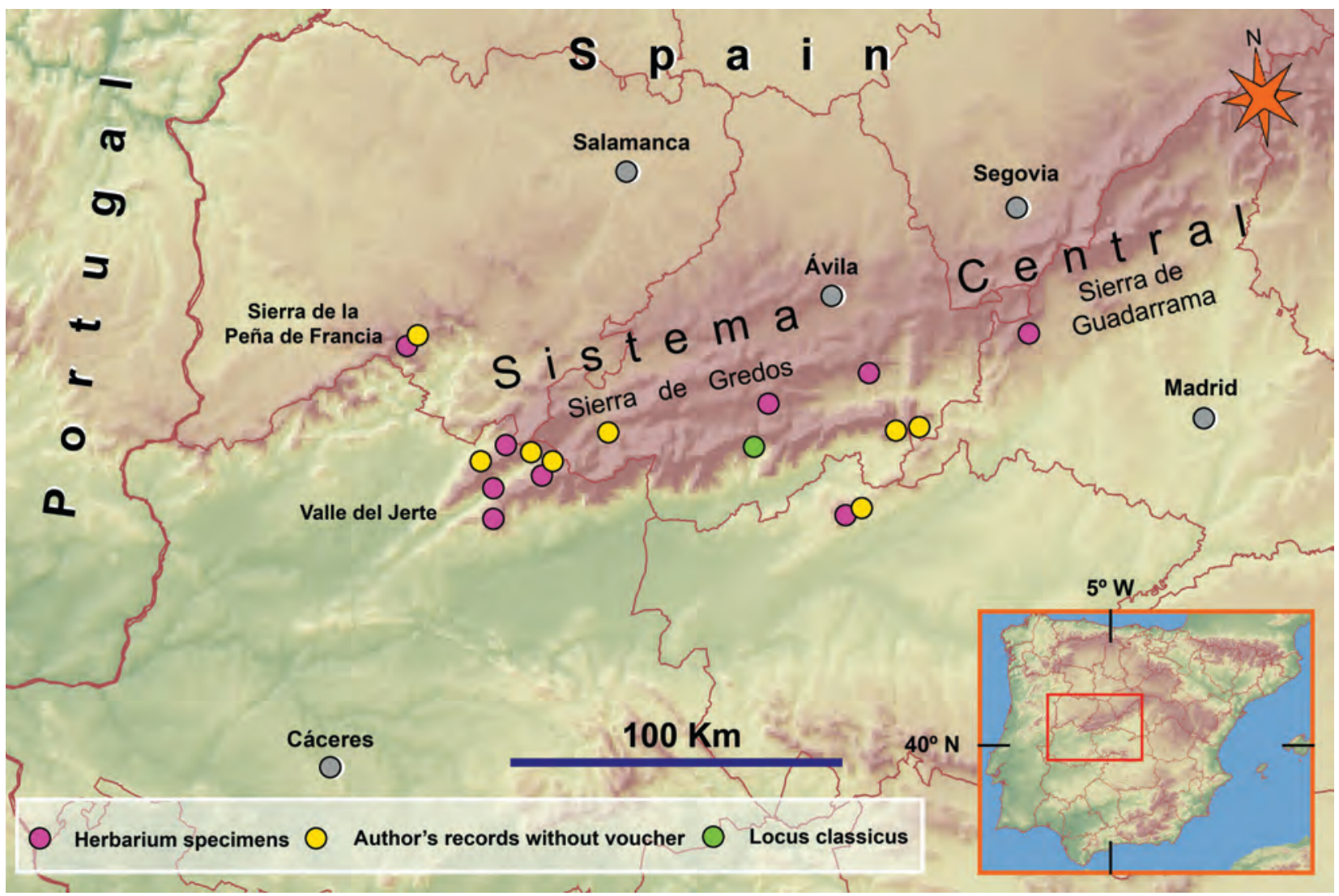

Fig. 3. Distribution map of Aristolochia castellana. 
Mediterranean region, this taxon distribution is fairly reduced (Fig. 3), this is also probably due to its ecology.

We can usually find it on the wooded slopes of the Sistema Central, usually in fresh and shady localities, preferring slightly acid substrates, which is typical of most of the Mediterranean species of this genus, associated with Quercus spp. (generally Q. pyrenaica), Castanea sativa or rarely Pinus spp., always growing intermixed with Aristolochia paucinervis.

It seems that its presence is correlated with the mountain system and with a mother rock of acid plutonic rock: its presently known distribution, based on herbarium specimens and personal records without voucher (see Appendix), strikingly coincides with the presence of this type of rock in the Sistema Central: Sierra de Gredos westward towards the Valle del Jerte (Cáceres) and a small, isolated area in the Sierra de la Peña de Francia (Salamanca; IGME, 1966; 1980).

Although this type of granite is also present in the north of Portugal and Galicia (N-W Spain), to date, no cited locality for this taxon in these areas is known. Of course more investigations would be worthwhile, but it may be that the climatic and ecological conditions are not the most adequate for this taxon.

Also, no locality is yet known in the Sierra de Guadarrama, the eastern part of the Sistema Central, north-east of the Sierra de Gredos, but in this area the mother rock is of a different type (IGME, 1966; 1980), which would seem to reinforce the idea of a possible relation between this taxon and the aforementioned geological characteristic, although exactly what type of relation still remains to be studied.

\section{Phylogenetic relationships}

The different groups of the Mediterranean species have been defined only on morphological bases (Nardi, 1984). A molecular phylogenetic study could resolve many questions, including the monophyly of the proposed groups.

Nonetheless, the morphological and cytological data described above could already help us to shed light on this subject with regarding $A$. castellana.

The main morphological feature of the $A$. pallida group is that of the petiole being very much longer than the peduncle (Nardi, 1984). The most common species of the group, A. lutea and A. pallida, both have a globous tuberous rootstock, whilst the other few, all narrow endemics (Nardi, 1984, 1989), have an elongated one. The chromosome numbers are $2 n=8 ; 10$, all diploids, with the exception of $A$. tyrrhena Nardi \& Arrigoni (an endemic from Sardinia and Corsica; Nardi \& Arrigoni, 1983), with $2 n=26$ (Nardi, 1984) and probably polyploid.
Hence, from a morphological and cytological point of view, $A$. castellana clearly belongs to this group.

The tuberous rootstock shape is worthy of comment. It may depend on some ecological adaptation, depending on the type and humidity of the substrate, the elongated type being more frequent in dry and stony soils and habitats. With regard to this question, the case of $A$. insularis Nardi \& Arrigoni (species belonging to the $A$. rotunda group; Nardi \& Arrigoni, 1983; Nardi, 1984) is extremely interesting. Described at the beginning as a proper species, differing from $A$. rotunda L. only in its elongated rootstock, it was later changed to a subspecies of the latter, $A$. rotunda subsp. insularis (Nardi \& Arr.) Gamisans (Nardi, 1985; Nardi \& Ricceri, 1987), after many intermediate individuals and populations had been found, demonstrating, at least in this case, a sort of variability between the two usually clearly distinguished shapes.

Coming back to $A$. castellana, we can consider it as the only member of the $A$. pallida group present in the Iberian Peninsula, the closest species, geographically, of this group being $A$. pallida, whose westernmost distribution limit is the Rhone Valley in France (Nardi, 1984; Ball \& al., 1993).

The $A$. longa group, whose most common member is A. paucinervis, is mainly morphologically characterized by the elongated rootstock and the short size of petiole and peduncle (Nardi, 1984). The chromosome numbers are $2 n=12 ; 24 ; 36$ (Nardi, 1984; Nardi \& Nesi Nardi, 1987), denoting the presence of polyploidy, even if a proper polyploid series has not yet been demonstrated.

Due to these characteristics, the relation of $A$. castellana to this group appears unlikely.

All the other taxa of Aristolochia present in the Iberian Peninsula are morphologically, cytologically, geographically and ecologically very distant from A. castellana.

Hybridization seems to be very rare in the genus, with only very few cases known worldwide (Blanco, 2005); no hybrid has yet been described for the Mediterranean species.

We might, therefore, describe $A$. castellana as a diploid taxon; the westernmost and only one present in the Iberian Peninsula at least distantly related to the A. pallida group species; with a narrow, localized distribution, restricted to a single mountain system, geologically well defined and isolated; spatially close to a polyploid, morphologically different species.

These observations render a recent origin of this taxon for speciation of a present Iberian species very unlikely.

Thus we might consider $A$. castellana a relict, en- 
demic (paleoendemic; Thompson, 2005), Iberian species.

\section{Acknowledgements}

I am extremely grateful to Dr. Ginés López González (Real Jardín Botánico, CSIC, Madrid, Spain), Dr. Nicolás López Jiménez (Universidad Complutense, Madrid, Spain), Prof. Christoph Neinhuis and Dr. Stefan Wanke (both of the Intitut für Botanik, Technische Universität Dresden, Germany) for their help, suggestions and fruitful conversations about the subject of the present work.

A special thanks to Dr. Ramón Velasco Gemio, director of the Reserva Natural de la Garganta de los Infiernos (Valle del Jerte, Cáceres, Extremadura, Spain), for his kind collaboration, for giving permission to study the populations included in this protected area. Many thanks also to Dr. Ricardo Castroviejo Bolibar (Universidad Politécnica de Madrid), for his kind explanations and comments about the geological situation of the Sistema Central.

Finally, I feel very grateful to the Editor-in-Chief and an Associate Editor of this Journal, whose numerous, keen comments have, I believe, increased, the quality of this small work.

\section{References}

Ball, P.W., Nardi, E. \& Akeroyd, J.R. 1993. Aristolochia L. In: Tutin, T.G., Burges, N.A., Chater, A.O., Edmondson, J.R., Heywood, V.H., Moore, D.M., Valentine, D.H., Walters, S.M. \& Webb, D.A. (eds.), Flora Europaea 1: 87-89, 2nd ed., Cambridge.

Blanco, M.A. 2005. Un híbrido espontáneo entre Aristolochia gorgona y A. grandiflora (Aristolochiaceae). Lankesteriana 5: 115-117.

Castroviejo, S. 1986. Aristolochiaceae. In: Castroviejo, S., Laínz, M., López González, G., Monserrat, P., Muñoz Garmendia, F., Paiva, J. \& Villar L. (eds.), Flora iberica 1: 201-205, Madrid.

Constantinidis, T., Kamari, G. \& Phitos, D. 1997. A cytological study of 28 phanerogams from the mountains of SE Sterea Ellas, Greece. Willdenowia 27: 121-142.

Costa, A. 2002. L'integrazione di tecniche morfologiche, citologiche e molecolari nelle indagini di tassonomia vegetale: il caso di alcuni taxa del gruppo Aristolochia pallida (Aristolochiaceae). Ph.D. thesis. Università degli Studi di Firenze (Italy).

Fabbri, F. \& Fagioli, A. 1971. Numeri cromosomici per la flora italiana: 19-22. Informatore Botanico Italiano 3: 51-55.

IGME, Aranguren Sabas, F. (director) 1966. Mapa geológico de la Península Ibérica, Baleares y Canarias; scale: 1:1,000,000; 5th edition, Madrid.

IGME, Garcia-Loygorri, A. (director) 1980. Mapa geológico de la Península Ibérica, Baleares y Canarias; scale: 1:1,000,000; 1st edition, Madrid.

Nardi, E. 1984. The genus Aristolochia L. (Aristolochiaceae) in Italy. Webbia 38: 221-300.

Nardi, E. 1985. Sulla tassonomia di Aristolochia insularis Nardi et Arr. Webbia 39: 119-127.

Nardi, E. 1988. De Aristolochiae pallidae Willd. subspecie nova in Hispania crescente. Webbia 42: 15-19.
Nardi, E. 1989. De speciebus Aristolochiae pallidae gregis (Aristolochiaceae) in Graecia crescentibus. Willdenowia 18:367-375.

Nardi, E. 1991. The genus Aristolochia L. (Aristolochiaceae) in Greece. Webbia 45:31-69.

Nardi, E. \& Arrigoni, P.V. 1983. Le piante endemiche della Sardegna: 134. Aristolochia tyrrhena Nardi et Arrigoni, species nova; 135. Aristolochia insularis Nardi et Arrigoni, species nova. Bollettino della Società Sarda di Scienze Naturali 22: 347-356.

Nardi, E. \& Nesi Nardi, C. 1987. Taxonomic and chorological notes on the genus Aristolochia L. (Aristolochiaceae) from the Central and Eastern Mediterranean area. Botanica Helvetica 97: 155-165.

Nardi, E. \& Ricceri, C. 1987. Il genere Aristolochia L. in Corsica. Webbia 41: 225-239.

Thompson, J.D. 2005. Plant Evolution in the Mediterranean: 4043, Oxford.

\section{Appendix}

\section{Herbarium specimens}

SPAIN. Ávila: El Barraco, Valle de Iruelas, Cañada del Perro, 5-V-1989, J.R. Molina s.n. (MACB 57804). Cuevas del Valle, 24-V1986, Nardi \& Nesi Nardi 8615 (typus, FI; isotypus, MA 485799). Hoyocasero, 5-VI-1992, 30TUK310728, F. Martínez García s.n. (MACB 76808). Cáceres: La Garganta, 5-VI-1976, Fernández Diez s.n. (MA 202936). Jerte,17-V-1995, M.A. Carrasco, J.M. Cardiel E S. Pajarón s.n. (MACB 60461; MA 582305). Pto. Piornal, 4-V1990, M.A. Carrasco ES S. Pajarón s.n. (MACB 35581; MA 504511). Puerto de El Piornal, 23-V-1991, M.A. Carrasco, A. Escudero E S. Pajarón s.n. (MACB 41363). Puerto del Piornal, vertiente N, 12V-1993, M.A. Carrasco, S. Pajarón E M.S. Borrado s.n. (MACB 49917; MA 529642). Valle del Jerte, castañar cerca del campamento "Emperador Carlos", 12-VI-1979, M.A. Carrasco \& M. Velayos s.n. (MACB 13131). Valle del Jerte, ribera del río, 18-IV-1975, Carrasco, Casaseca \& Castroviejo s.n. (MACB 13127). Madrid: El Escorial, 18-VI-1992, 30TVK019956, F. Martínez García s.n. (MACB 76809). Salamanca: La Alberca, 14-V-1981, Fernández Diez s.n. (MACB 8771). Toledo: Hinojosa de San Vicente, Monte San Vicente, sobre el collado del Piélago, 2-VI-2002, 30TUK5344, V.J. Arán 5173 E M.J. Tohá (MAF 163160). Sierra de San Vicente, 11-V-1993, M.A. Carrasco, S. Pajarón E M.S. Borrado s.n. (MACB 49897)

\section{Populations visited by the author without voucher}

SPAIN. Ávila: Alto del Mirlo, Casillas, 6-VI-2000, 30TUK66. Barco de Ávila, 19-VI-2005, 30TTK86. Casillas, 19-VI-2005, 30TUK66. Cáceres: Hervás, 19-VI-2005, 30TTK56. Valle del Jerte, Tornavacas, Dehesa La Campana, Paraje de Pedro Miguel, 18-VI-2005, 30TTK76. Valle del Jerte, Tornavacas, Reserva de la Garganta de los Infiernos, Garganta de San Martín, la Casa Blanca, 18-VI-2005, 30TTK75. Madrid: Alto del Mirlo, Rozas de Puerto Real, 6-VI-2000, 30TUK66. Salamanca: La Alberca, Las Batuecas, 19-VI-2005, 29TQE48. Toledo: Sierra de San Vicente, Navamorcuende, VI-2005, 30TUK54.

Associate Editor: J. Devesa Received: 8-I-2008 Accepted: 5-VI-2008 